\title{
眝留施設の機能評価のための水文地図とその利用例
}

Regional Analysis of Parameters in the Expressions of Efficiency of Urban Storages

$\begin{array}{lll}\text { 近畿大学理工学部 } & \text { 加 納 祐 啓 Masanori KANOH } \\ \text { 近畿大学理工学部 } & \text { 江 藤 剛 治 Takeharu ETOH }\end{array}$

Hydrologic maps are presented, which are used to estimate values of the parameters in the expressions of efficiency of urban storage facilities to control flood, water supply and quality. The expressions have been derived by the authors. AMeDAS, the automated meteorological data acquisition system of the Japanese meteorological agency, supplies hourly rainfall data at more than 1300 observatories deployed all over the Japanese islands, and enables to calculate the parameters. Examples to explain how to use the maps are also presented.

Keywords: regional analysis, hydrologic maps, storage facilities, AMeDAS

1.はじめに

以前より，各種の水文量を表示した水文地図の作成の必要性について述べてきた。本報告では，中小の 河川流域を対象とした眝留施設の機能を評価するための水文地図を提示し，この利用法を示す。

著者らはすでに，眝留施設の機能を評価するための 2 つの式を導いた。

(1) 治水を目的とする場合 ： 所与の治水安全度を確保するのに必要な排水施設の容量と眝留施設の容 量との関係を表す等危険度線の式。

（2) 利水（および水質保全）を目的とする場合 ： 雨水眝留施設の利水勃果を表す利用率の式。

その後、これら2つの式について，必要なパラメーターの值を全国の雨量資料 (アメダス雨量資料)を 用いて求めてきた。これらの值を日本地図上に等高線で表示し, さらに,できあがった水文地図の利用法 について検討してきた。今回, 現時点で得られる一通りの水文地図が完成し，その利用法についても実用 的と考えられる方式が固まってきたので報告する。

\section{2. 作成した水文地図}

(1) 治水を目的とする場合 ${ }^{11}$

標準等危険度線の式は, 次式で表される。

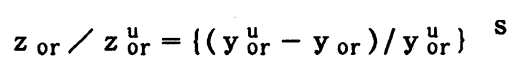

ここに, $\quad$ y or : 所与の治水安全度を排水施設だけで確保するのに必要な雨量換算排水容量。 $\mathbf{z}$ or : 所与の治水安全度を眝留施設だけで確保するのに必要な雨量换算眝留容量。 $\mathrm{s}: \mathrm{y}$ or と $\mathrm{z}$ or $\mathrm{u}$ をむぶ曲線の曲率。

式(1) は, 雨量単位で表されているので,これをもとの容量に変換するには次式を用いる。

$$
y_{0}=f_{P} A \text { is } y_{\text {or }} / 3.6, \quad z_{0}=1000 f A z_{\text {or }}
$$

ここに，A は流域面積 $\left(\mathrm{km}^{2}\right) ， \mathrm{f}$ は流出率， $\mathrm{f}_{\mathrm{P}}$ はピーク流出係数である。 i s は D D関係から決まる 補正係数で, 次式で表される。 


$$
\mathrm{i}_{\mathrm{s}}=\mathrm{a} /\left(\mathrm{t}_{\mathrm{p}}^{\mathrm{c}}+\mathrm{b}\right) \quad\left(\mathrm{t}_{\mathrm{P}} \text { は洪水到達時間 }\right)
$$

標準等危険度線を利用するのに必要なパラメーターは， y or ， z or , s , a , b , c の6つである。 (2) 利水 (および水質保全) を目的とする場合 2 ( $~ 4)$

利用率の式は，次式で表される。

$$
\varepsilon=\mathrm{C}\left\{1-\exp \left(-Z_{o}^{\prime} / \mathrm{C}\right)\right\}
$$

ここに,

$$
\begin{aligned}
& Z_{\mathrm{o}}^{\prime}=Z_{\mathrm{o}}-\mathrm{c}_{\mathrm{Zd}_{\mathrm{d}}} Z_{\mathrm{d}}^{\prime}+\mathrm{D} \mathrm{T} \mathrm{r}_{\mathrm{r}} \\
& Z_{\mathrm{d}}^{\prime}=Z_{0}-2 \cdot \ln \left\{2-\exp \left(-Z_{0} / 2\right)\right\} \\
& \left\{\begin{array}{lll}
C=D, & c_{z d}=\sqrt{D} & (D \leqq 1 の と き) \\
C=1, & c_{z d}=1 / \sqrt{D} & (D>1 \text { のとき })
\end{array}\right.
\end{aligned}
$$

$\mathrm{D}, Z_{\mathrm{o}}, \mathrm{T}_{\mathrm{r}}$ は無次元量で表した単位時間当りの利用水量, 眝留施設の容量, 一雨流出継続時間であ り, 次式で表される。

$$
\mathrm{D}=\overline{\mathrm{t}_{\mathrm{R}}} \cdot \mathrm{d} / \overline{\mathrm{v}}, \quad \mathrm{Z}_{\mathrm{o}}=\mathrm{z}_{\mathrm{o}} / \overline{\mathrm{v}}, \quad \mathrm{T}_{\mathrm{r}}=\overline{\mathrm{t}_{\mathrm{r}}} / \overline{\mathrm{t}_{\mathrm{R}}}
$$

利用率を求めるのに必要な諸量を表一 1 に示す。この うち，降雨特性から与えられるパラメーターは， $\overline{\mathrm{r}}$, $\overline{t_{R}}, \overline{t_{r}}$ の3つである。

\begin{tabular}{|c|c|c|c|}
\hline 降雨指標 & $\begin{array}{l}\text { 平均一電雨量 } \\
\text { 平均流出時間間隔 } \\
\text { 平均流出継続時間 }\end{array}$ & $\frac{\overline{\frac{T}{t_{R}}}}{\frac{t_{r}}{r}}$ & $\begin{array}{l}(\mathrm{mm} / \mathrm{hr}) \\
(\mathrm{hr}) \\
(\mathrm{hr})\end{array}$ \\
\hline 流出特性 & 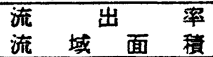 & $\begin{array}{l}\mathrm{f} \\
\mathrm{A}\end{array}$ & $\left(\mathrm{km}^{2}\right)$ \\
\hline 施設容量 & $\begin{array}{l}\text { 眝留容 } \\
\text { 単位時間当たりの } \\
\text { 使用水量 }\end{array}$ & $\begin{array}{l}z_{0} \\
d\end{array}$ & $\begin{array}{l}\left(m^{3}\right) \\
\left(m^{3} / h r\right)\end{array}$ \\
\hline \multirow[t]{2}{*}{ 注 } & 平均一雨総流出量 & \multirow{2}{*}{\multicolumn{2}{|c|}{$\begin{array}{l}\bar{v}\left(m^{3}\right) \\
=1000 \cdot \mathrm{f} \cdot \overline{\mathrm{A}} \cdot \mathrm{A}\end{array}$}} \\
\hline & 流出任不浸 & & \\
\hline
\end{tabular}

\section{3. 水文地図の作成法}

著者らは,アメダスの観測点での各種水文量の值の大 きさによって色分けをした水文地図を作成してきたす）6 ある地点の持つ各種水文量の値が簡単に利用できるよう

表- 1 利用率の計算に必要な諸量

にすることが水文地図作成の目的の 1 つである。色分けによる水文地図からある地点の数值を読み取るこ とは困難である。数值で表すため，等高線で描くことにした7)。これまでは手作業で等高線図を作成して きたが,この方法では個人の主観が入ってくる。また非常に多くの労力が必要になってくる。したがって， コンピューター・グラフィックスを用いて自動的に等高線図を描く方法を試みた。

一定間隔のメッシュ情報から等高線を描くことは比較的簡単である。しかし，アメダスの観湖所は，全 国均一には設置されていない。また，1976 年から 1985 年の 10 年間の資料すべてが使用できる観測所 は, 1317 観測所の内 778 観測所だけである。観測所の数は約6 割になり, 特に多雪地域ではまばらな状 態になる。この状態のまま等高線図を描くのは困難である。さらに, 今後観測所の移動・增加・減少等が あった場合に，それに対応していくことも困難になってくる。ここでは，メッシュ情報をアメダス観測点 から推定し，等高線を作成する。ティスプレイの精度の関係からメッシュ幅は6分とした。

ある地点の気象特性は，周辺の観測所の資料から推定する。対象とする地点から半径 $50 \mathrm{~km}$ 以内の観測 所を推定に用いた。理由は以下の通りである。

観測所のない地点の値を推定するので，できるだけ多くの観測所の資料を用いた方がよい。半径を大き くとれば，多くの観測所の資料を用いることができる。しかし，地点間の雨量の相関係数は，近似的に， 距離が大きくなるにつれて指数関数的に減衰すると考えられる。相関性を判断する場合，一般に相関係数

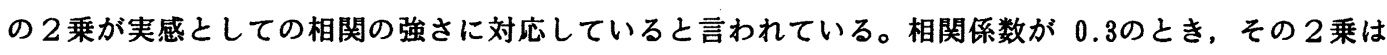
0.1 以下となり，ほぼ相関がないと判断してもよいであろう。北海道の各時間単位の年最大雨量資料につ

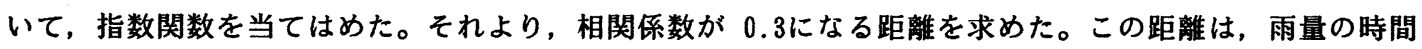


単位が大きくなるにつれて大きくなる。しかしある時間単位にな ると，その距離は一定となる。これを図ー 1 に示す。約 5 時間よ り大きな時間単位になると，相関を無視できる距離は時間単位に 関係なく一定になる ${ }^{8)}$ 。半径 $50 \mathrm{~km}$ 程度までは相関がかなり高く, 推定に用いてもよいであろうと考えた。

あるメッシュの交点から半径 $50 \mathrm{~km}$ 以内にあるアメダス観測所 产 の数値を用いて, その地点の値を推定する。以下にその式を示す。

$$
\mathrm{H}_{i}=\sum_{j=1}^{n}\left(h_{j} / L_{j}^{2}\right) / \sum_{j=1}^{n}\left(1 / L_{j}^{2}\right)
$$

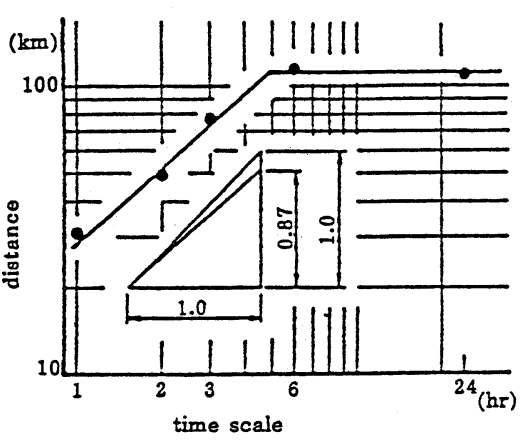

図一 1 時間規模之距離との関係

ここに, $\mathrm{n}$ は $\mathrm{i}$ 番目のメッシュの交点から半径 $50 \mathrm{~km}$ 以内のアメダス観測所の数, $\mathrm{h}$ ，は $\mathrm{j}$ 番目のアメダ ス観測所が持つ各種水文量の値， $\mathrm{L}$ ，は $\mathrm{i}$ 番目のメッシュ点と $\mathrm{j}$ 番目の観測点との距離である。すなわち， あるメッシュの交点から半径 $50 \mathrm{~km}$ 以内にあるアメダス観測所から, 距離の 2 乗に反比例させて, そのメ ッシュの交点の数值を決めている。観測所の数 $\mathrm{n}$ が 4 以上になるメッシュの交点でのみ数值を求め, 等高 線を描くための情報として使用した。

\section{4. 治水を目的とした場合の水文地罒の利用例}

作成した水文地図を図ー 3 に示す。平均再㴆間隔 5 年のもの を示している。1 例として, 四中矢印の地点を対象として考え る。図より, $y_{\text {or }}^{u}=30 \mathrm{~mm} / \mathrm{hr}, z_{\text {or }}^{u}=100 \mathrm{~mm}, \mathrm{~s}=3.8$ である ことがわかる。これらのパラメーターの値を式(1) に代入する ことによって標準等危険度線を描くことができる。

降雨量時系列において，降雨継続時間とピーク雨量との間に 相関はほとんどない。この場合，地域にかかわらず，理論的に $\mathrm{s}=3 \sim 3.2$ になる9 ${ }^{9}$ 。 $\mathrm{s}$ の水文地図をみると，ほとんどの地 域で 3 以上になっている。表一 2 に $\mathrm{s}$ の值の統計量を, 図- 2 にその頻度分布を示す。実測値から得られた $\mathrm{s}$ の值の平均値は, 3.67 になっており, 理論よりやや大きいが, ほぼうまく一致 している。

表 $-2 \quad \mathrm{~s}$ の統計量

\begin{tabular}{|c|c|}
\hline 平 均 值 & 3.674 \\
\hline 標準偏差 & 0.742 \\
\hline 最 大 值 & 10.000 \\
\hline 最 小 & 1.691 \\
\hline
\end{tabular}

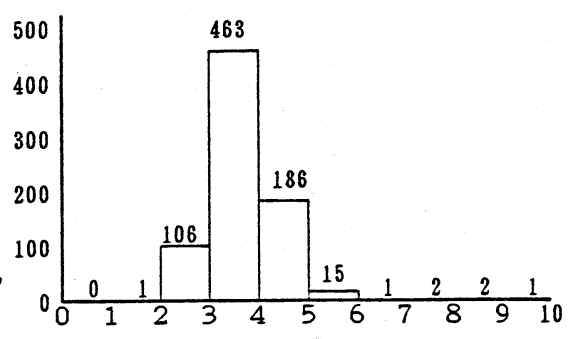

図-2 $\mathrm{s}$ の頻度分布

$\mathrm{s}$ の値として小さい值を採用する方が安全㑡の計画を策定することになる。計画段階では $\mathrm{s}=3$ の値を 用いれば，ほとんどの地域で安全側の計画になる。約 1 割の地域で, $\mathrm{s}$ の值が3より小さくなっている。 その地域では水文地図から得られた值を用いればよいであろう。 $\mathrm{s}$ の值は平均再帰間隔にかかわらずほぼ 同じ値になる。

標準等危険度線は雨量単位（四/ $\mathrm{hr}$ とmm）で表されており、これからもとの流量単位に戻すには， 式(2) 中の i s (基準化降雨強度と呼ぶ) が必要になってくる。これは, 式(3) で使われているパラメー 夕ー a , b , c の值をそれぞれの水文地図から求め, 代入することで得られる。図より，a=1.8, b= $0.8, c=0.7$ であることがわかる。これらの值は平均再帰間隔が変わってもほとんど同じである。 $\mathrm{s}, \mathrm{a}, \mathrm{b}, \mathrm{c}$ の值は異なった平均再帰間隔であってもほぼ等しいので, 平均再㷌間隔の異なった等危 険度線を描く場合においても，必要な平均再帰間隔の $\mathrm{y}$ or $， \mathrm{z}_{\mathrm{or}}^{\mathrm{u}}$ の水文地図を加えるだけでよい。また, $\mathrm{y}$ or,$\quad z$ or 足求めるときの確率分布関数に使われているパラメーターの值を水文地図として表しておけば, 色々な平均再帰間隔の $\mathrm{y}$ or,$\quad \mathrm{z}$ or の水文地図を作成しなくてもよい。

作成した標準等危険度線図の利用法については，参考文献1），10）に詳しく述へててい。 


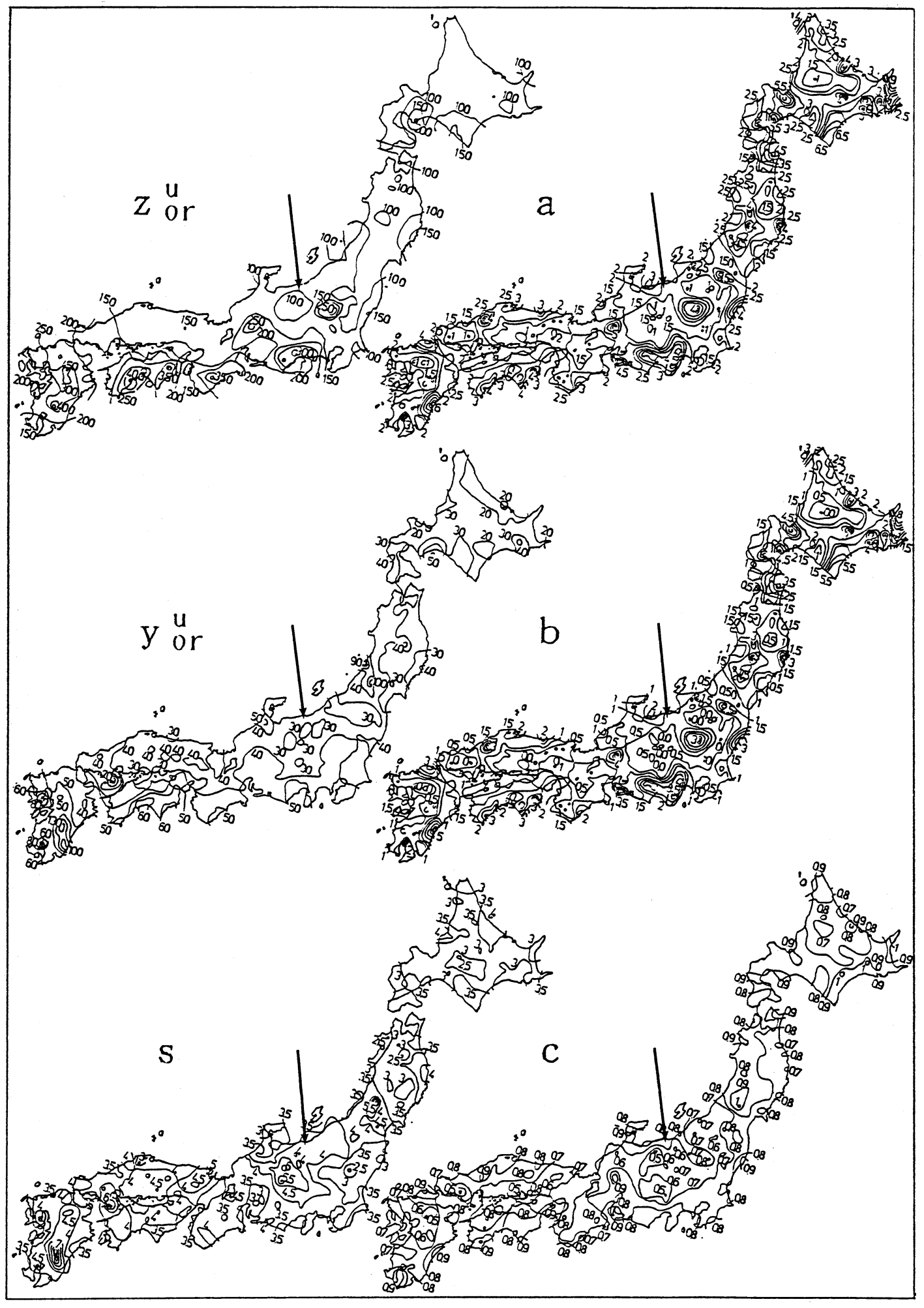

図ー3 治水を目的とした水文地図 


\section{5. 利水（水質保全）を目的とする場合の水文地図の利用例}

都市河川流域においては，ハイドログラフとハイエトグラフの相似性が極めて高く，雨量資料を用いて 必要なパラメーターを表しておけは，流域面積の変化等に簡単にかっ有効に利用できる。このことは，標 準等危険度線を作成するための議論においてすでに明らかにしている ${ }^{1)}$ 。同様に，利水を目的とする場合 においても，上記のパラメーターを雨量単位で表しておけば，これも簡単かつ有効に利用することができ る。

たとえば，利用率の式については，結果として時間雨量時系列に次のような微修正をほどこした後の時 系列を用いる。無降雨状態が 3 時間以上継続した時, その前後の雨は別々の一雨とする。都市河川流域に おいては, ある一連の降雨が生じたとき初期に 2 m程度の損失 (凹地眝留) があることが知られている。 すべての一雨降雨から初期損失として最初の 2 吅を差し引く。したがって, 2 㥸以下の一雨は, 流出しな いものとする。このようにして作成した降雨量時系列を使って上記のパラメーターの值を求める。 $\overline{\mathbf{v}}$, $\overline{\mathrm{t}_{\mathrm{R}}}, \overline{\mathrm{t}_{\mathrm{r}}}$ をそれぞれ, 平均一雨雨量, 平均一雨時間間隔, 平均一雨継続時間を使って表示する。 $\overline{\mathrm{t}}_{\mathrm{R}}$, $\overline{\mathrm{t}}_{\mathrm{r}}$ はそのまま利用できる。复については, 流出係数, 流域面積がわかれば簡単に換算できる。

作成した水文地図を図ー4，5に示す。4，の場合と同様に，図中矢印の地点を対象として考える。 たとえば眝留容量 $z_{0}=500 \mathrm{~m}^{3}$ ，利用（目標）水量 $\mathrm{d}=5 \mathrm{~m}^{3} / \mathrm{hr} \quad\left(=120 \mathrm{~m}^{3} / \mathrm{day}\right)$ ，流域面積 $\mathrm{A}=15.000 \mathrm{~m}^{2}=0.015 \mathrm{~km}^{2}$ とする。水文地図より, 平均流出継続時間 $\overline{\mathrm{t}_{\mathrm{r}}}=7.0 \mathrm{hr}$, 平均流出時間 間隔 $\overline{\mathrm{t}_{\mathrm{R}}}=160 \mathrm{hr}(=6.67 \mathrm{day})$, 平均一雨雨量 $\overline{\mathrm{r}}=14 \mathrm{~mm}$ 読み取れる。表一 1 中の式に $\overline{\mathrm{r}}$ を代入す ると, 平均一雨総流出量 $\overline{\mathrm{v}}=168 \mathrm{~m}^{3}$ となる。

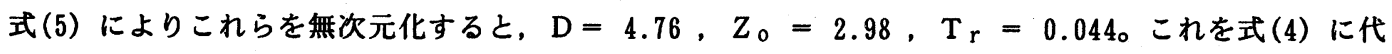
入すると，利用率 $\varepsilon=90 \%$ \%る。実際に利用できる水量は平均して $120 \times 0.9=108 \mathrm{~m}^{3} / \mathrm{day}$ 。 上水道から補給すべき不足水量は，平均すると $120-108=12 \mathrm{~m}^{3} / \mathrm{day}$ 。ただし眝留施設が空になった

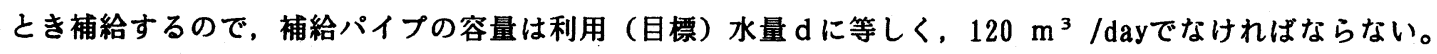
すなわち雨水眝留施設は, 本来の水源であるダムの水の使用量の低下, すなわち水位の低下には若干では あっても寄与するが, 一旦渴水時に入ったときは, 雨水眝留施設に依存していた水量の全てが上水道に依 存することになることを注意しておく。眝留施設が空になって，上水道から給水する期間の率は，100一 $90=10 \%$ \%ある。逆に利用率之, 利用 (目標) 水量を与えて, 必要眝留容量を求めることなども容易 である。

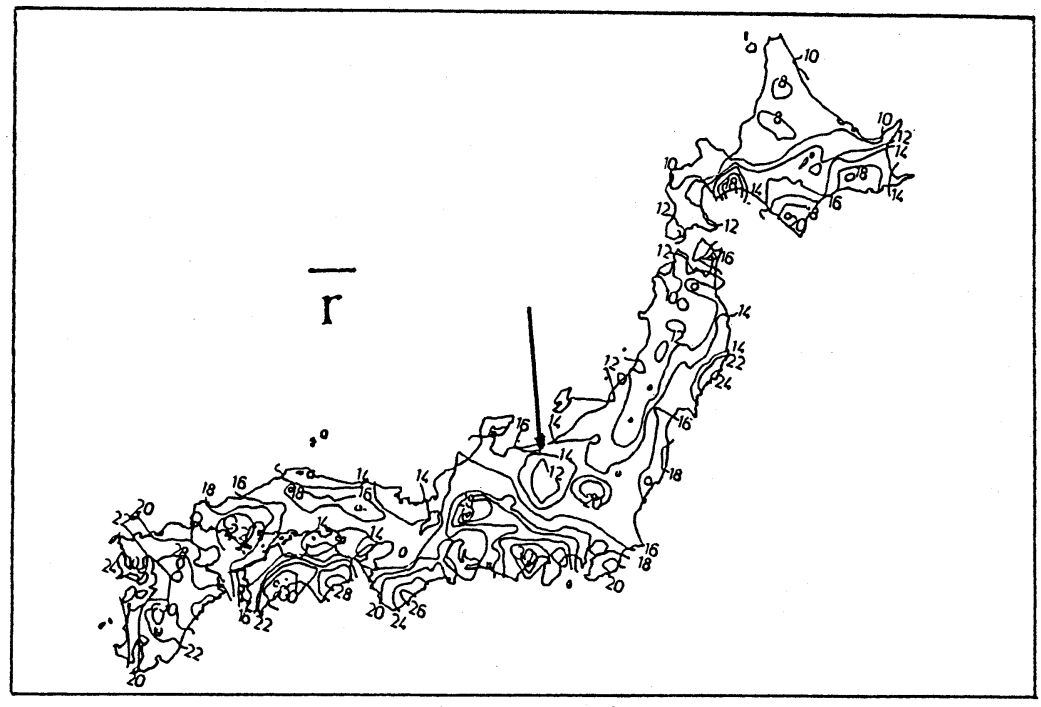

図 -4 利水を目的とした水文地図 


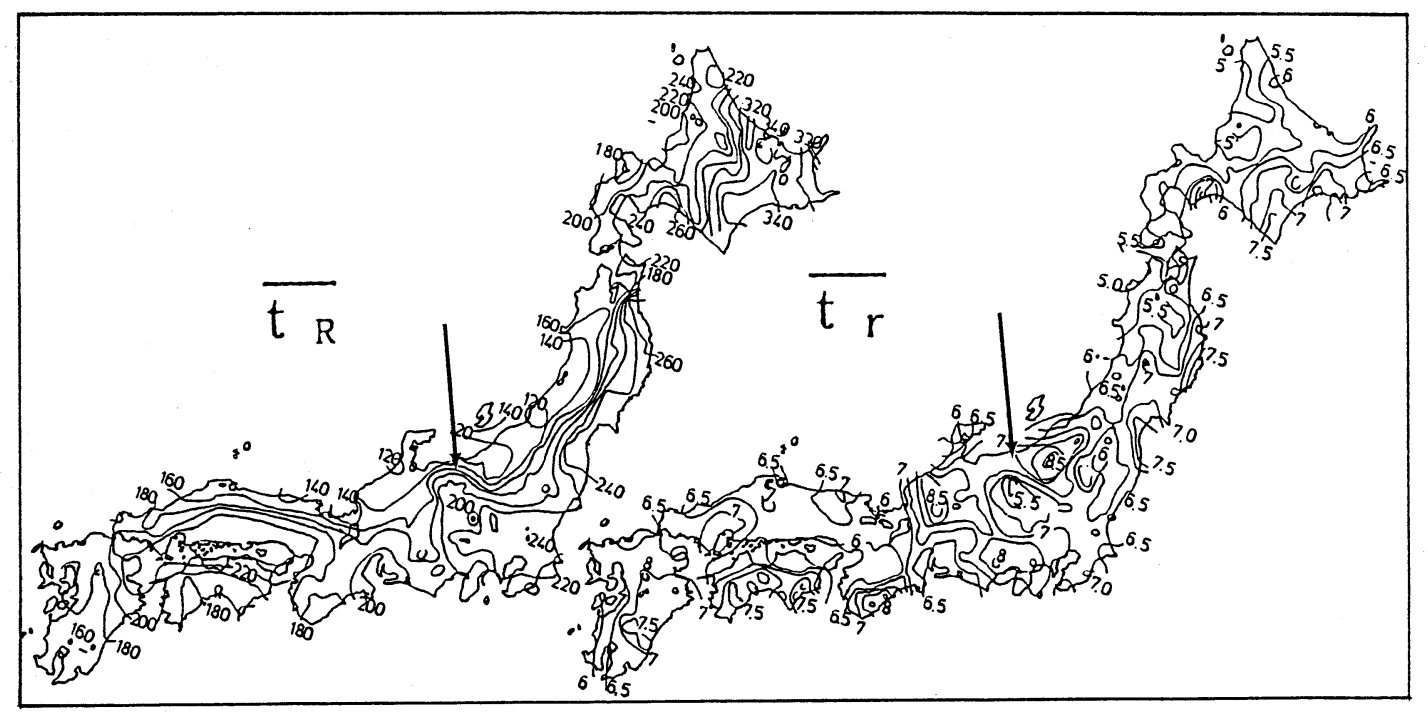

図ー 5 利水を目的とした水文地図

\section{6.おわりに}

中小河川流域に構築された雨水眝留施設の治水・利水機能を評価するための水文地図が完成した。この 水文地図の利用法について示した。

アメタススの観測所のように，全国に散在する観测所の資料から等高線を描く手法を示した。

\section{[参考文献]}

1）室田明・江藤剛治・中西祐啓 : 標準等危険度線による都市河川の治水安全度評価，土木学会論文集， №.369/I1-5, pp.155-164, 1986.

2）江藤剛治・栗田秀明 : 雨水眝留施設の利水勃果, 第31回水理講演会論文集, pp.283-286, 1987.

3）江藤㓮治 : 雨水眝留施設の治水・利水および水質改善効果, 第 3 回水資源に関するシンポジウム, pp.155-160, 1987.

4）加納祐啓・江藤剛治：AMeDASによる水文地図の作成例一雨水眝留施設の利水効果を評価する場合一, 土木学会第 43 回年次学術講演会, pp.154-155, 1988.10.

5）江藤剛治・中西祐啓 : 水文地図作成の試み一雨水眝留施設の機能評価を目的とする場合一，土木学会 第42回年次学術講演会, pp.2-3, 1987.

6）加納祐啓・江藤剛治：AMeDASによる水文地図の作成例，土木学会第 43回年次学術講演会, pp.154$155,1988$.

7）江藤剛治・中西祐啓・池田吉隆：AMeDASによる等危険度線マップの作成，第31回水理講演会論文集， pp. 265-270, 1987.

8）中西祐啓・江藤剛治：北海道の大雨の頻度, 近畿大学理工学部研究報告, 第 22 号, pp.47-55, 1986.

9）江藤剛治・室田明・柳本速雄 : 眝留施設と排水施設を併用した高水計画の安全性, 第28回水理講演会 論文集, pp.359-367, 1984 .

10）中西祐啓・室田明・江藤判治 : 眝留施設の治水勃果に関する実際的な評価の例, 第 29 回水理講演会論 文集, pp.311-316, 1985 . 